\title{
PENGUJIAN KEMAMPUAN MENGINTERPRETASIKAN GRAFIK KINEMATIKA CALON GURU FISIKA: THE POLYTOMOUS RASCH ANALYSIS
}

\author{
Unang Purwana ${ }^{1,2)}$, Dadi Rusdiana ${ }^{2,3)}$, Winny Liliawati ${ }^{1)}$ \\ 1)Program Studi Pendidikan Fisika, FPMIPA, Universitas Pendidikan Indonesia, Bandung, Indonesia \\ ${ }^{2)}$ Program Studi Pendidikan IPA, Sekolah Pascasarjana, Universitas Pendidikan Indonesia, Bandung, Indonesia \\ 3)Program Studi Fisika, FPMIPA, Universitas Pendidikan Indonesia, Bandung, Indonesia \\ Corresponding author: Winny Liliawati \\ E-mail : winny@upi.edu
}

Diterima 23 Oktober 2020, Direvisi 04 November 2020, Disetujui 05 November 2020

\begin{abstract}
ABSTRAK
Kemampuan interpretasi grafik merupakan kemampuan yang sangat penting dan kunci utama dalam memahami materi kinematika dan materi fisika lanjutan. Namun kemampuan interpretasi grafik materi kinematika mahasiswa calon guru masih rendah. Tujuan penelitian ini menguji kemampuan membaca dan menginterpretasikan grafik kinematika calon guru dengan analisis polytomous rasch model. Instrumen terdiri dari empat soal uraian menyajikan grafik kinematika. Tes diberikan ke 20 mahasiswa calon guru, terdiri dari 14 perempuan dan 6 laki-laki. Metode yang digunakan survei deskriptif kuantitatif dengan analisis menggunakan rasch model dengan data politomi. Hasil yang diperoleh nilai reliabilitas 0,58 kategori lemah, tingkat kesukaran untuk 3 soal dalam kategori sukar dan satu soal kategori mudah, daya pembeda berkategori sangat baik untuk seluruh soal. Kemampuan membaca dan menginterpretasikan grafik kinematika secara keseluruhan cukup baik. Kesimpulannya instrumen dan analisis yang digunakan dapat menguji kemampuan menginterpretasikan grafik kinematika calon guru.
\end{abstract}

Kata kunci: interpretasi; grafik, kinematika; polytomous rasch.

\begin{abstract}
The ability to interpret graphs is a very important ability and the main key in understanding kinematics and advanced physics materials. However, the ability to interpret graphs of prospective teachers is still low. The purpose of this study is to test the ability to read and interpret the kinematic graphs of prospective teachers using polytomous rasch model analysis. The instrument consists of four essay questions presenting a kinematic graph. The test was given to 20 prospective teachers, consisting of 14 females and 6 males. The method used is quantitative descriptive survey with analysis using the rasch model with polytomous data. The results obtained were the reliability value of 0.58 in the weak category, the level of difficulty for 3 questions in the difficult category and one question in the easy category, the distinguishing power was very good for all the questions. The overall ability to read and interpret kinematics graphs is quite good. In conclusion, the instruments and analysis used can test the ability to interpret the prospective teacher's kinematics graph.
\end{abstract}

Keywords: interpretation; graph; kinematics; polytomous.

\section{PENDAHULUAN}

Materi kinematika merupakan materi yang dipelajari di Fisika Dasar. Materi dasar untuk dapat memahami konsep-konsep selanjutnya di fisika (Amin et al., 2020; Parmalo, Y., Djudin, T., \& Oktavianty, 2016). Apabila mahasiswa kurang memahami konsep kinematika dengan baik maka mahasiswa akan mengalami kesulitan dalam memahami materi fisika lanjut (Amin et al., 2020; Parmalo, Y., Djudin, T., \& Oktavianty, 2016). Sehingga materi kinematika sebagai materi fundamental di fisika (Amin et al., 2020; Manurung, Mihardi, Rustaman, \& Siregar, 2018; Parmalo, Y., Djudin, T., \& Oktavianty, 2016).
Materi Kinematika banyak menyajikan dan menggunakan grafik dalam memahami aspek fisis dari gerak suatu benda. Besaran fisis dalam kinematika dapat ditampilkan dalam bentuk hubungan grafik antara besaran seperti grafik hubungan antara posisi terhadap dan waktu, kecepatan terhadap waktu, dan percepatan terhadap waktu. Melalui analisis grafik, besaran kinematika lainnya dapat diperoleh. Penggunaan grafik lebih baik daripada penggunaan teks karena grafik memudahkan untuk mencari dan menemukan informasi terkait (Bektasli, 2006, 2012; Manurung et al., 2018). Grafik dapat digunakan sebagai alternatif untuk memahami konsep 
kinematika (Amin et al., 2020). Penggunaan rumus fisika dapat diminimalkan melalui grafik. Beberapa persamaan fisika dalam kinematika diperoleh melalui grafik. Grafik kinematika sebagai alternatif untuk memanipulasi pengembangan konsep (Kekule, 2014). Oleh karena itu, pengetahuan mahasiswa tentang bagaimana menginterpretasikan grafik kinematika penting untuk diajarkan (Subali, Rusdiana, Firman, \& Kaniawati, 2015). Keterampilan membuat dan membaca grafik merupakan faktor kunci dalam mempelajari materi kinematika dan Fisika secara umumnya, serta menggambar dan menafsirkan grafik memainkan peran kunci dalam memahami sains (Amin et al., 2020; Karamustafaoğlu, 2011; Kukliansky, 2016; Redding, 2014; Sharma, 2013; Yustiandi \& Saepuzaman, 2017). Jika kemampuan membaca dan menginterpretasikan grafik mahasiswa lemah, maka akan berdampak pada rendahnya pemahaman mahasiswa tentang konsep kinematika (Amin et al., 2020; Manurung et al., 2018; Subali et al., 2015).

Selama ini siswa di sekolah menengah hingga mahasiswa kesulitan dalam membaca dan menginterpretasi grafik (Amin et al., 2020; Bunawan, Setiawan, Rusli, \& ., 2015; Manurung et al., 2018; Petrova, 2016; Setyono, Nugroho, \& Yulianti, 2016; Subali et al., 2015; Uzun, Sezen, \& Bulbul, 2012; Yustiandi \& Saepuzaman, 2017), dikarenakan beranggapan grafik sebagai gambar, kemiringan grafik sebagai tinggi grafik, menganggap garis grafik sebagai lintasan gerak suatu benda (Kekule, 2014; Manurung et al., 2018; Salameh \& Aldhamit, 2014), membedakan antara kemiringan dan ketinggian grafik; menafsirkan perubahan ketinggian dan perubahan kemiringan grafik, menghubungkan satu jenis grafik ke yang lain, menafsirkan area di bawah grafik, kesulitan menentukan variabel dan besaran pada grafik yang disajikan (Amin et al., 2020; Nugraha, Saehana, \& Darsikin, 2016), kesulitan mentransformasi informasi berdasarkan grafik (Amin et al., 2020; Pujianto, 2013; Zavala, Tejeda, Barniol, \& Beichner, 2017), kesulitan menyatakan hubungan antar variabel pada grafik (Amin et al., 2020; Nugraha et al., 2016; Parmalo, Y., Djudin, T., \& Oktavianty, 2016; Rahmawati, Ali, \& Kendek, 2014; Vaara \& Sasaki, 2019), belum memahami gerak lurus beraturan dan gerak lurus berubah beraturan (Amin et al., 2020; Maries \& Singh, 2013).

Penelitian ini bertujuan untuk menguji kemampuan membaca dan menginterpretasikan grafik kinematika pada mahasiswa calon guru. Hal ini perlu dilakukan untuk memetakan kesulitan mahasiswa calon guru dalam memahami kinematika. Guru merupakan garda terdepan dalam kemajuan Pendidikan di Indonesia dan sebagai calon guru Fisika di masa depan.

\section{METODE PENELITIAN}

Tujuan penelitian ini menguji kemampuan membaca dan menginterpretasi grafik materi kinematika gerak pada calon guru fisika di sekolah menengah atas. Oleh karena itu menggunakan metode deskriptif kuantitatif. Sehingga diperoleh gambaran profil keterampilan membaca grafik dan interpretasi grafik jarak terhadap waktu, kecepatan terhadap waktu, dan percepatan terhadap waktu pada gerak lurus beraturan dan gerak lurus berubah beraturan dengan analisis secara kuantitatif.

Populasi penelitian ini adalah mahasiswa yang mengikuti perkuliahan Mata Kuliah Mekanika untuk Sekolah di semester tiga (3) tahun akademik 2019-2020 yang tersebar di tiga kelas. Partisipan penelitian ini dipilih hanya satu dari tiga kelas, berjumlah 20 mahasiswa calon guru, 14 perempuan dan 6 laki-laki. Pemilihan kelas yang dipilih berdasarkan kelas yang diampu oleh peneliti sehingga bersifat studi kasus.

Pengumpulan data kemampuan membaca dan menginterpretasikan grafik kinematika diperoleh melalui tes uraian yang terintegrasi dengan materi subjek pembelajaran Kinematika Gerak Lurus. Tes diberikan setelah mahasiswa mengikuti perkuliahan Mata Kuliah Mekanika untuk Sekolah. Tes uraian berjumlah empat (4) soal, yang mengujikan grafik hubungan jarak terhadap waktu, kecepatan terhadap waktu, dan percepatan terhadap waktu dari gerak lurus beraturan dan gerak lurus berubah beraturan. Setiap soal terdiri dari 2-5 pertanyaan dari suatu grafik. Rincian soal kemampuan membaca dan menginterpretasikan grafik diberikan oleh Tabel 1.

Tabel 1. Rincian soal kemampuan membaca dan menginterpretasikan grafik

\begin{tabular}{|c|c|c|}
\hline Grafik & $\begin{array}{l}\text { Kemampuan yang } \\
\text { diukur }\end{array}$ & No Soal \\
\hline $\begin{array}{l}\text { Jarak terhadap } \\
\text { waktu (GLB) }\end{array}$ & $\begin{array}{l}\text { Menentukan } \\
\text { perpindahan dan } \\
\text { kecepatan }\end{array}$ & $\begin{array}{l}1 a, 1 b \\
1 c, 1 d\end{array}$ \\
\hline $\begin{array}{l}\text { Kecepatan } \\
\text { terhadap waktu }\end{array}$ & $\begin{array}{l}\text { Menentukan } \\
\text { perpindahan, } \\
\text { kecepatan dan } \\
\text { percepatan }\end{array}$ & $\begin{array}{l}2 \mathrm{a}, 2 \mathrm{~b}, \\
2 \mathrm{c}, 2 \mathrm{~d}, \\
2 \mathrm{e}\end{array}$ \\
\hline $\begin{array}{l}\text { Kecepatan } \\
\text { terhadap waktu } \\
\text { Percepatan } \\
\text { terhadap waktu }\end{array}$ & $\begin{array}{l}\text { Menentukan } \\
\text { hubungan } \\
\text { kecepatan dan } \\
\text { percepatan }\end{array}$ & $\begin{array}{l}3 a, 3 b \\
3 c, 3 d\end{array}$ \\
\hline $\begin{array}{l}\text { Jarak terhadap } \\
\text { waktu (GLBB) }\end{array}$ & $\begin{array}{l}\text { Menentukan jarak, } \\
\text { kecepatan dan } \\
\text { percepatan }\end{array}$ & $4 a, 4 b$ \\
\hline
\end{tabular}


Setiap soal dilengkapi dengan rubrik penilaian yang memiliki empat kategori yaitu Paham (P), Cenderung Paham (CP), Kurang Paham (KP) dan Tidak Paham (TP). Dikatakan paham bila seluruh pertanyaan di setiap soal dijawab betul, cenderung paham bila $25-50 \%$ menjawab betul, kurang paham jika $50-75 \%$ menjawab salah, dan tidak paham jika seluruh soal dijawab salah.

Data kemampuan membaca dan menginterpretasikan grafik berupa data ordinal dengan skala 1-4. Analisis data menggunakan analisis statistika inferensi dan analisis politomus rasch model. Pada analisis Rasch dilakukan pengonversian skor butir yang diukur menjadi satuan logit atau logarithm odds unit (Park, T., Liu, M. Y., Wang, T. C., \& Zhu, 2019). Skor yang diperoleh merupakan data politomi yang kemudian diolah menggunakan software Winisteps Versi 4. 4.1. Reliabilitas instrumen dapat dilihat dari tiga aspek yaitu reliabilitas item, reliabilitas person dan nilai Alpha Cronbach.

Kemampuan membaca dan menginterpretasikan grafik dapat diketahui melalui perolehan skor logit berdasarkan tabel Person Measure (Sumintono, 2015). Pada tabel person tersebut diperoleh informasi nilai logit pada setiap mahasiswa. Nilai logit yang paling tinggi menunjukkan tingkat kemampuan mahasiswa yang tinggi. Analisis kemampuan mahasiswa dapat dilihat pada outliers atau misfit pada masing-masing butir soal. Kriteria yang digunakan untuk mengetahui kesesuaian antara soal dengan kemampuan menginterpretasikan grafik mahasiswa yaitu dari Outfit Mean Square (MNSQ) yang diterima: $0,5<\mathrm{MNSQ}<1,5$, atau nilai Outfit Z-Standar (ZSTD) yang diterima: $-2,0<$ ZSTD $<+2,0$ (Sumintono, 2015). Selain itu, kita dapat melihat sebaran perbedaan kemampuan membaca dan menginterpretasikan grafik mahasiswa dari Wright Map item person.

\section{HASIL DAN PEMBAHASAN Karakteristik Instrumen}

Uji reliabilitas menggunakan software MINISTEP 4.4.1. pada menu output 3.1 Summary Statistics yang fungsinya yaitu untuk menampilkan beberapa nilai reliabilitas, diantaranya adalah person reliability, item reliability, dan Cronbach alpha. Soal berjumlah 4 soal dengan diberikan kode $E$ dan dilanjutkan oleh angka 1 sampai dengan 4 (seperti: E1, E2, E3, E4). Hasil uji reliabilitas butir soal dapat dilihat pada Tabel 2 berikut:
Tabel 2. Reliabilitas Person, Item dan Alpha cronbach

\begin{tabular}{llll}
\hline & Separation & Reliability & $\begin{array}{l}\text { Alpha } \\
\text { Cronbach }\end{array}$ \\
\hline Person & 0,62 & 0,28 & \\
\cline { 1 - 2 } Item & 0,00 & 0,00 & 0,58 \\
\hline
\end{tabular}

Berdasarkan nilai person reliability sebesar 0,28, artinya konsistensi jawaban mahasiswa berada dalam kategori lemah. Kemudian untuk nilai item reliability sebesar 0,00 , artinya kualitas item tes yang digunakan berada dalam kategori lemah. Cronbach Alpha sebesar 0,58 dengan kategori jelek artinya kurangnya interaksi antara person dan butir secara keseluruhan. Hal ini dipengaruhi oleh jumlah soal dan jumlah responden yang relatif sedikit dalam suatu sampel uji coba soal. Semakin banyak jumlah sampel maka akan menghasilkan reliabilitas yang sangat baik. Reliabilitas menjelaskan seberapa jauh pengukuran yang dilakukan berkali-kali akan menghasilkan informasi yang sama (Sumintono, 2015). Analisis reliabilitas dapat melihat reliabilitas stabilitas instrumen. Reliabilitas stabilitas digunakan untuk mengetahui apakah sebuah instrumen yang dikenakan kepada orang yang sama dan dalam kondisi yang sama, namun dalam waktu yang berbeda akan memberikan hasil yang hampir sama dan setara.

Tingkat kesukaran soal dapat diketahui dengan menggunakan software MINISTEP 4.3.1 pada menu output Table 1 Variable (Wright) maps dan output Table 13 Item Measure yang dianalisis dengan Rasch. Hasil menu output Table 1 Variable (Wright) maps soal setelah diolah dalam MINISTEP dapat dilihat pada Gambar 1 variabel (wright) maps sebagai berikut.

Gambar 1 variabel wright maps secara garis besar hanya menggambarkan kekuatan soal yang sudah dijawab oleh mahasiswa. Pada bagian kanan di dalam gambar, kode $E$ yang diikuti angka menunjukkan nomor butir soal. Selanjutnya pada bagian kiri, kode L (Laki-laki) atau $P$ (Perempuan) secara berurutan menunjukkan mahasiswa laki-laki dan perempuan. Pada Gambar terlihat bahwa semua soal yakni E1, E2, E3, dan E4 berpotensi masih bisa dijawab oleh mahasiswa. Menu output Variable (Wright) maps disini untuk menunjukan secara umum bagaimana potensi instrumen soal tersebut dijawab oleh mahasiswa, untuk lebih jelasnya dapat dilihat melalui menu output Table 13 Item Measure. 


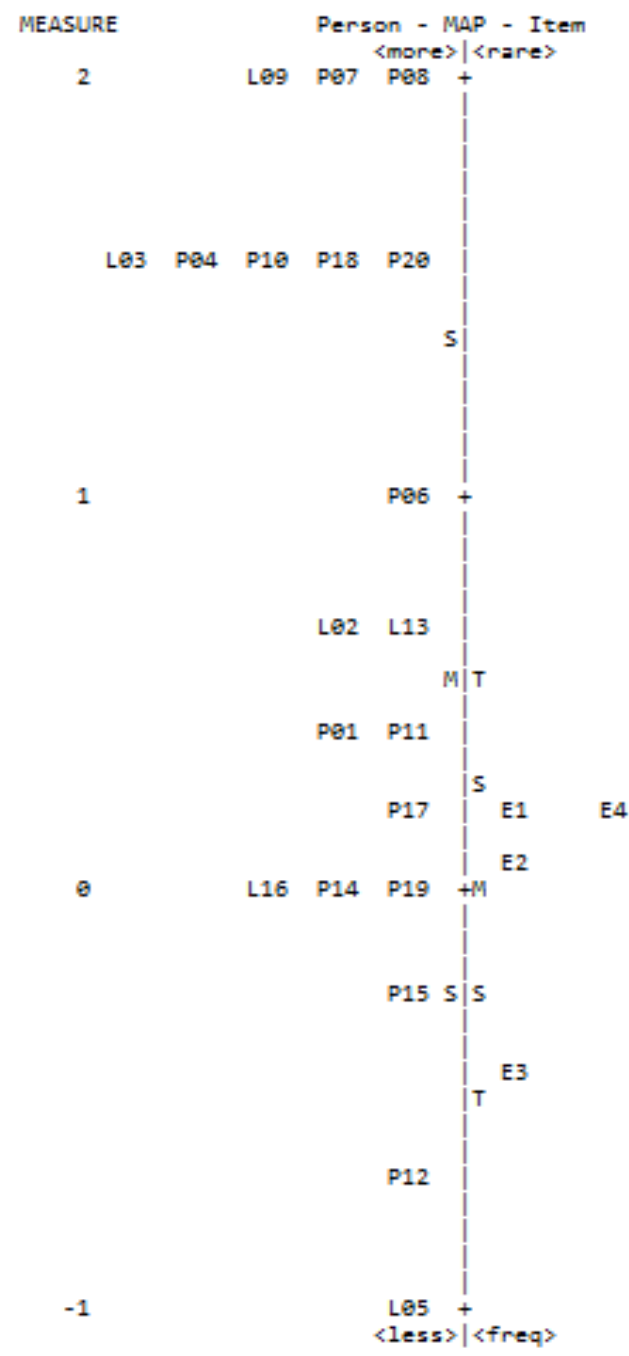

\section{Gambar 1. Menu Output Variable (Wright) maps}

Hasil analisis tingkat kesukaran instrumen soal setelah diolah dalam MINISTEP dapat dilihat pada menu output Table 13 Item Measure sebagai berikut:

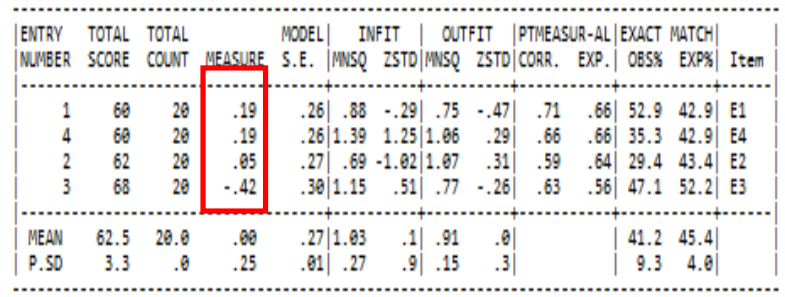

Gambar 2. Menu Output Item Measure

Pada Gambar 2 menunjukkan soal nomor 1 dengan kode E1 pada kolom Item memiliki nilai measure paling tinggi dengan logit (logarithm odd unit) sebesar 0,19 sedangkan soal nomor 3 dengan kode E3 memiliki nilai measure paling rendah dengan logit sebesar 0,42 . Hasil berikutnya pada output ini mengenai nilai Standar Deviasi (SD) soal menunjukan angka 0,25 , artinya dari standar deviasi tersebut dapat dibuat klasifikasi kategori tingkat kesulitan instrumen soalnya. Menurut Sumintono \& Widhiarso (2015) menyatakan bahwa nilai 0,00 logit +1 SD adalah satu kelompok sukar, lebih besar dari +1 SD adalah soal yang sangat sukar; 0,00 logit -1SD adalah soal yang mudah; dan lebih kecil dari -1SD soal yang sangat mudah. Berdasarkan hal tersebut, tingkat kesulitan setiap item dapat diinterpretasikan seperti Tabel 3 berikut.

Tabel 3. Hasil tingkat kesukaran tiap butir tes dengan analisis Rasch

\begin{tabular}{lll}
\hline No. & Tingkat & Interpretasi \\
Soal & Kesukaran (TK) & Sukar \\
\hline E1 & 0,19 & Sukar \\
E2 & 0,05 & Mudah \\
E3 & $-0,42$ & Sukar \\
E4 & 0,19 & \\
\hline
\end{tabular}

Hasil interpretasi tiap butir soal pada Tabel 3 menunjukkan bahwa soal dengan tingkat kesukaran berbeda-beda, mulai dari kategori mudah sebanyak 1 soal dengan persentase $25 \%$ yaitu soal nomor 3; dan kategori sukar sebanyak 3 soal dengan persentase $75 \%$ yaitu soal nomor 1,2 , dan 4 . Soal yang mudah berkaitan dengan hubungan antara grafik kecepatan terhadap waktu dengan grafik percepatan terhadap waktu.

Tingkat kesukaran untuk tes berada pada dua kategori yaitu tiga soal kategori sukar dan satu soal kategori mudah. Untuk soal yang mudah berkaitan dengan hubungan antara grafik kecepatan terhadap waktu dengan grafik percepatan terhadap waktu. Untuk tiga soal yang sukar berkaitan dengan membaca dan menginterpretasikan grafik posisi terhadap waktu, kecepatan terhadap waktu dan percepatan terhadap waktu. Hal ini dikarena mahasiswa menganggap garis grafik sebagai lintasan gerak suatu benda (Kekule, 2014; Manurung et al., 2018; Salameh \& Aldhamit, 2014), kesulitan menentukan besaran posisi, kecepatan dan percepatan pada grafik (Amin et al., 2020; Nugraha et al., 2016), kesulitan menyatakan hubungan posisi, kecepatan dan percepatan pada grafik (Amin et al., 2020; Nugraha et al., 2016; Parmalo, Y., Djudin, T., \& Oktavianty, 2016; Rahmawati et al., 2014; Vaara \& Sasaki, 2019). Kesimpulannya mahasiswa belum paham gerak lurus beraturan dan gerak lurus berubah beraturan. Sesuai dengan temuan Maries \& Singh (2013) dan Amin dkk (2020). 
Daya pembeda pada soal dapat diketahui menggunakan software MINISTEP 4.3.1 dengan menu output Table 10 Item Fit Order yang dianalisis dengan Rasch. Penggunaan Point Measure Correlation (Pt Mean Corr) dapat memberikan informasi mengenai daya pembeda dari suatu instrumen soal yang digunakan untuk membedakan kemampuan mahasiswa. Adarqun nilai Point Measure Correlation (Pt Mean Corr) untuk soal dapat dilihat pada Gambar 3 berikut:

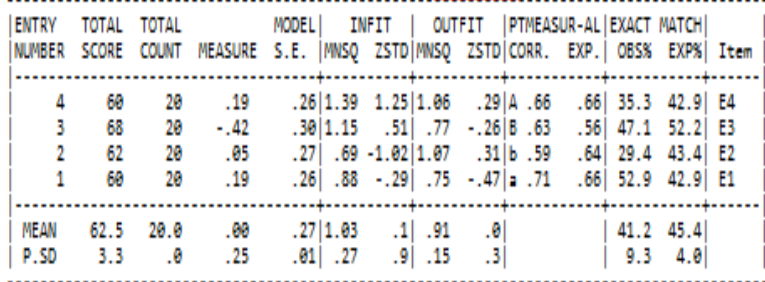

Gambar 3. Menu Output item (column): fit order

Untuk dapat mengetahui kategori daya pembeda tiap butir soal pada kolom $P T$ MEASURE CORR., dapat dicari dengan interpretasi dengan mengacu nilai Pt Mean Corr. Sehingga interpretasi daya pembeda untuk tiap butir soal dapat dilihat pada Tabel 4 berikut.

Tabel 4. Interpretasi daya pembeda untuk setiap butir soal

\begin{tabular}{|c|c|c|}
\hline No. Soal & Pt Mean Corr & Interpretasi \\
\hline E1 & 0,71 & Sanqat Baik \\
\hline E2 & 0.59 & Sanqat Baik \\
\hline E3 & 0,63 & Sangat Baik \\
\hline E4 & 0,66 & Sangat Baik \\
\hline
\end{tabular}

Berdasarkan Tabel 4 diperoleh hasil semua soal termasuk pada kriteria sangat baik untuk daya pembeda seluruh soal. Soal dapat membedakan mana kelompok atau mahasiswa yang memiliki kemampuan tinggi dengan kemampuan rendah.

\section{Kemampuan menginterpretasikan grafik kinematika}

Kemampuan mahasiswa dalam menjawab soal dapat diketahui dengan menggunakan software MINISTEP 4.3.1 pada menu output Table 1 Variable (Wright) maps yaitu menu yang juga menampilkan tingkat kesukaran soal yang dianalisis dengan Rasch. Hasil menu output Table 1 Variable (Wright) maps soal setelah diolah dalam MINISTEP dapat dilihat pada gambar variabel (wright) maps sebagai berikut (Gambar 4).

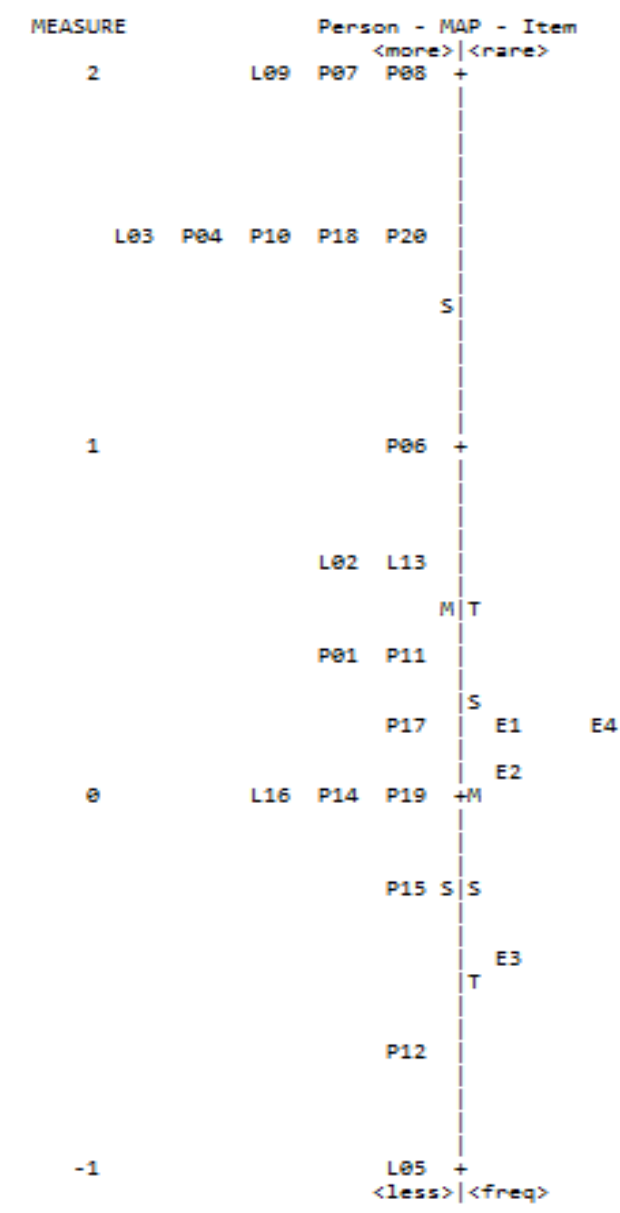

Gambar 4. Menu Output Variable (Wright)
maps

Pada bagian kiri di dalam gambar, kode L (Laki-laki) atau P (Perempuan) secara berurutan menunjukkan mahasiswa laki-laki dan perempuan serta diikuti dengan angka dimana angka menunjukkan nomor urut mahasiswa. Pada Gambar terlihat bahwa mahasiswa dengan kode L09, P07 dan P08 merupakan mahasiswa dengan kemampuan paling tinggi. Sedangkan mahasiswa yang memiliki nilai kemampuan tinggi tidak hanya ketiga mahasiswa tersebut namun mahasiswa dengan kode L03, P04, P10, P18, P20, P6, L2, L13, P1, P11 juga memiliki kemampuan tinggi. Ketiga belas mahasiswa tersebut lebih tinggi dari semua tingkat kesulitan soal yang diberikan, hal ini berarti bahwa ketiga belasnya akan mendapatkan nilai maksimum yang bisa didapatkan.

Pada bagian kiri peta, terdapat juga dua orang mahasiswa dengan kemampuan sangat rendah (P12 dan L05), L05 merupakan mahasiswa dengan kemampuan paling rendah. Kedua mahasiswa tersebut tidak mampu untuk mengerjakan dengan benar soal dengan kesulitan yang paling rendah, yaitu butir soal E3. 
Berdasarkan hasil rekapitulasi kemampuan membaca dan interpretasi grafik ditunjukkan pada Tabel 5.

Tabel 5. Rekapitulasi Kemampuan Interpretasi Grafik

\begin{tabular}{lcccc}
\hline Kategori & $\begin{array}{l}\text { Soal } \\
\text { No 1 }\end{array}$ & $\begin{array}{c}\text { Soal } \\
\text { No 2 }\end{array}$ & $\begin{array}{c}\text { Soal } \\
\text { No 3 }\end{array}$ & $\begin{array}{c}\text { Soal } \\
\text { No 4 }\end{array}$ \\
\hline Paham & $50 \%$ & $25 \%$ & $80 \%$ & $65 \%$ \\
$\begin{array}{l}\text { Cenderung } \\
\text { Paham }\end{array}$ & $15 \%$ & $60 \%$ & $0 \%$ & $0 \%$ \\
Kurang Paham & $20 \%$ & $15 \%$ & $0 \%$ & $5 \%$ \\
Tidak Paham & $15 \%$ & $0 \%$ & $20 \%$ & $30 \%$ \\
\hline
\end{tabular}

Berdasarkan Tabel 5, soal no 3 merupakan soal yang paling mudah sesuai dengan hasil yang ditunjukkan pada Gambar 4. Persentase mahasiswa yang paham lebih tinggi dari yang lainnya.

Kemampuan mahasiswa dalam membaca grafik sudah cukup baik, pemahaman mahasiswa di atas 50\% kecuali soal nomor 2. Soal nomor 2 dapat dikatakan soal yang paling sulit karena hanya $25 \%$ mahasiswa yang paham. Sedangkan $60 \%$ mahasiswa cenderung paham maksudnya pemahaman mahasiswa tidak utuh atau hanya paham sebagian, Soal nomor dua menampilkan grafik kecepatan terhadap waktu, ditunjukkan pada Gambar 5 berikut:

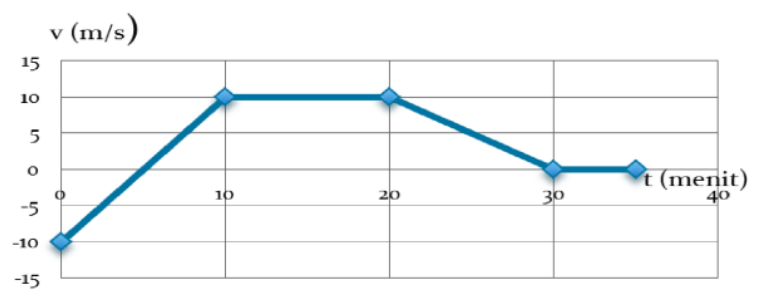

Gambar 5. Soal Nomor 2

Sebagian besar mahasiswa kesulitan memahami makna fisis kecepatan bernilai negatif. Hal ini karena mahasiswa tidak memahami besaran fisis dan variabel di grafik. Besaran yang dimaksud yaitu kecepatan sebagai besaran vektor yang bertanda negatif. Mahasiswa beranggapan garis grafik sebagai lintasan gerak suatu benda (Kekule, 2014; Manurung et al., 2018; Salameh \& Aldhamit, 2014), kesulitan menentukan besaran kecepatan pada grafik (Nugraha et al., 2016), dan tidak dapat membedakan kelajuan dan kecepatan. Hal ini sesuai dengan temuan Pujianto dkk. (2013), bahwa siswa sulit membedakan antara konsep kelajuan dan kecepatan. Miskonsepsi ini diawali ketika mahasiswa tidak mampu menentukan jarak dan perpindahannya (Setyono et al., 2016).

\section{SIMPULAN DAN SARAN}

Instrumen yang digunakan dapat mengungkap kemampuan membaca dan menginterpretasikan grafik kinematika calon guru SMA, meskipun nilai reliabilitas yang lemah. Mahasiswa calon guru dapat membaca dan membaca grafik secara keseluruhan cukup baik. Namun ditemukan kemampuan menginterpretasikan grafik kecepatan terhadap waktu, dengan kecepatan bernilai negatif masih kesulitan. Kurang dapat membedakan konsep kecepatan dan kelajuan, Untuk kelanjutan penelitian ini, agar menghasilkan reliabilitas yang tinggi maka gunakan jumlah sampel yang banyak untuk pengujian instrumen. Untuk pembelajaran, ditekankan konsep kecepatan, kelajuan, jarak, dan perpindahan.

\section{UCAPAN TERIMAKASIH}

Ucapan terimakasih ditujukan kepada mahasiswa dan dosen-dosen di Departemen Pendidikan Fisika FPMIPA UPI yang telah memberikan kontribusi lain dalam penelitian

\section{DAFTAR RUJUKAN}

Amin, B. D., Sahib, E. P., Harianto, Y. I., Patandean, A. J., Herman, \& Sujiono, E. H. (2020). The interpreting ability on science kinematics graphs of senior high school students in South Sulawesi, Indonesia. Jurnal Pendidikan IPA Indonesia. https://doi.org/10.15294/jpii.v9i2.23349

Bektasli, B. (2006). The Relationships Between Spatial Ability, Logical Thinking, Mathematics Performance And Kinematics Graph Interpretation Skills Of 12th Grade Physics Students. Interpretation A Journal of Bible And Theology.

Bektasli, B. (2012). The Relationships between Logical Thinking, Gender, and Kinematics Graph Interpretation Skills. Eurasian Journal of Educational Research, 48, 119.

Bunawan, W., Setiawan, A., Rusli, A., \&. N. (2015). Penilaian Pemahaman Representasi Grafik Materi Optika Geometri Menggunakan Tes Diagnostik. Jurnal Cakrawala Pendidikan, 2(2), 257267.

https://doi.org/10.21831/cp.v2i2.4830

Karamustafaoğlu, S. (2011). Improving the Science Process Skills Ability of Science Student Teachers Using I Diagrams. Eurasian J. Phys. Chem. Educ, 3(1), 2638. Retrieved from http://www.eurasianjournals.com/index.ph p/ejpce

Kekule, M. (2014). Students' approaches when dealing with kinematics graphs explored 
by eye-tracking research method. Proceedings of the Frontiers in Mathematics and Science Education Research Conference, (May), 108-117.

Kukliansky, I. (2016). Student's Conceptions in Statistical Graph's Interpretation. International Journal of Higher Education, $5(4)$.

https://doi.org/10.5430/ijhe.v5n4p262

Manurung, S. R., Mihardi, S., Rustaman, N. Y., \& Siregar, N. (2018). Improvement of Graph Interpretation Ability Using Hypertext-Assisted Kinematic Learning and Formal Thinking Ability. Jurnal Pendidikan Fisika Indonesia, 14(1), 1-6. https://doi.org/10.15294/jpfi.v14i1.9444

Maries, A., \& Singh, C. (2013). Exploring one aspect of pedagogical content knowledge of teaching assistants using the test of understanding graphs in kinematics. Physical Review Special Topics - Physics Education Research, 9(2), 1-14. https://doi.org/10.1103/PhysRevSTPER.9 .020120

Nugraha, A., Saehana, S., \& Darsikin. (2016). Kesulitan Siswa Dalam Menyelesaikan Permasalahan Grafik Kinematika. Jurnal Inovasi Dan Pembelajaran Fisika, 77-88.

Park, T., Liu, M. Y., Wang, T. C., \& Zhu, J. Y. (2019). Semantic image synthesis with spatially-adaptive normalization. In Proceedings of the IEEE Conference on Computer Vision and Pattern Recognition (pp. 2337-2346). Retrieved from http://www.ghbook.ir/index.php?name=مج مو عه مقالات دومين هم انديشى سراسرى رسانه تلويزيون/. 9

سكو لاريسم\&option=com dbook\&task=reado nline\&book_id $=13629 \&$ page $=108 \&$ chkha shk $=03 C 706812 F \&$ ltemid $=218 \&$ lang $=f a \& t$ $\mathrm{mpl}=$ component

Parmalo, Y., Djudin, T., \& Oktavianty, E. (2016). Deskripsi Kemampuan Menafsirkan Grafik Kinematika Siswa Kelas X SMA Negeri 3 Sungai Kakap. Jurnal Pendidikan Dan Pembelajaran Khatulistiwa, 5(7), 1140.

Petrova, H. G. (2016). Developing Students , Graphic Skills In Physics Education At Secondary School. Journal of Research and Method in Education, 6(5), 123-126. https://doi.org/10.9790/7388060501123126

Pujianto, A. (2013). Analisis Konsepsi Siswa Pada Konsep Kinematika Gerak Lurus. JPFT (Jurnal Pendidikan Fisika Tadulako Online), 1(1), 16-21. https://doi.org/10.22487/j25805924.2013. v1.i1.2370

Rahmawati, L. F., Ali, M., \& Kendek, Y. (2014).
Perbedaan Hasil Belajar Fisika Antara Model Pembelajaran Sains Teknologi Masyarakat Dan Model Pembelajaran Direct Instruction Pada Siswa Kelas $\mathrm{X}$ Sma Negeri 1 Palu. JPFT (Jurnal Pendidikan Fisika Tadulako Online), 1(1), 48-54.

https://doi.org/10.22487/j25805924.2013. v1.i1.2473

Redding, C. W. (2014). Effect of Predicting Motion on Student Understanding of Kinematic Graphs. LSU Master's Theses, (August).

Salameh, M., \& Aldhamit, Y. (2014). The Effect of Computer Simulation on Al-Hussein Bin Talal University $S$ tudent, $\mathrm{S}$ Understanding of Electricity and Magnetism Concepts and their Attitudes towared Physics Learning. International Journal of Educational Research and Technology, 5(March), 54-60.

Setyono, A., Nugroho, S. E., \& Yulianti, I. (2016). Analisis Kesulitan Siswa Dalam Memecahkan Masalah Fisika Berbentuk Grafik. UPEJ Unnes Physics Education Journal, 5(3), 32-39. https://doi.org/10.15294/upej.v5i3.13729

Sharma, S. (2013). Assessing Students ' Understandıng of Tables and Graphs: Implications for Teachıng and Research. International Journal of Educational Research and Technology, 4(December), 51-70.

Subali, B., Rusdiana, D., Firman, H., \& Kaniawati, I. (2015). Analisis Kemampuan Interpretasi Grafik Kinematika pada Mahasiswa Calon Guru Fisika. Prosiding Simposium Nasional Inovasi Dan Pembelajaran Sains 2015 (SNIPS 2015), 2015(Snips), 269-272.

Sumintono, B. (2015). Aplikasi Pemodelan Rasch pada Assessment Pendidikan. Trim Komunikata.

Uzun, M. S., Sezen, N., \& Bulbul, A. (2012). Investigating Student's Abilities Related to Graphing Skill. Procedia - Social and Behavioral Sciences, 46(1990), 29422946.

https://doi.org/10.1016/j.sbspro.2012.05.5 94

Vaara, R. L., \& Sasaki, D. G. G. (2019). Teaching kinematic graphs in an undergraduate course using an active methodology mediated by video analysis. Lumat, 7(1), 1-26. https://doi.org/10.31129/LUMAT.7.1.374

Yustiandi, \& Saepuzaman, D. (2017). Profil Kemampuan Interpretasi Grafik Kinematika Siswa SMA Kelas X. Gravity: Jurnal Ilmiah Penelitian Dan 
Pembelajaran Fisika, 3(1), 30-39.

Zavala, G., Tejeda, S., Barniol, P., \& Beichner, R. J. (2017). Modifying the test of understanding graphs in kinematics. Physical Review Physics Education Research, 13(2), 1-16. https://doi.org/10.1103/PhysRevPhysEdu cRes.13.020111 